ISSN (print): 1698-6180. ISSN (online): 1886-7995

www.ucm.es/info/estratig/journal.htm

Journal of Iberian Geology 38 (1) 2012: 239-251

http://dx.doi.org/10.5209/rev_JIGE.2012.v38.n1.39216

\title{
Paleoseismic and geomorphologic evidence of recent tectonic activity of the Pozohondo Fault (Betic Cordillera, SE Spain)
}

\author{
Evidencias paleosísmicas y geomorfológicas de actividad tectónica reciente de \\ la Falla de Pozohondo (Cordillera Bética, SE de España)
}

\author{
M.A. Rodríguez-Pascua*1, R. Pérez-López ${ }^{1}$, V.H. Garduño-Monroy², J.L. Giner-Robles ${ }^{3}$, \\ P.G. Silva ${ }^{4}$, M.A. Perucha-Atienza ${ }^{1}$, V.M. Hernández-Madrigal ${ }^{2}$, J. Bischoff 5 \\ ${ }^{1} I G M E-$ Instituto Geológico y Minero de España. Ríos Rosas, 23. 28003-Madrid. Spain \\ ma.rodriguez@igme.es; r.perez@igme.es \\ ${ }^{2}$ Universidad Michoacana de San Nicolás de Hidalgo. Morelia. Michoacán. 58060-Mexico \\ vgmonroy@umich.mx \\ ${ }^{3}$ Facultad de Ciencias. Universidad Autónoma de Madrid. Cantoblanco. 28049-Tres Cantos. Madrid. Spain \\ jorge.giner@uam.es \\ ${ }^{4}$ Dpto. Geología, Escuela Politécnica Superior de Avila, Universidad de Salamanca. Avda. Hornos Caleros, 50. \\ 05003-Ávila. Spain \\ pgsilva@usal.es \\ ${ }^{5}$ USGS- 345 Middlefield Road, MS 211, Menlo Park, CA 94025, USA. \\ jbischoff@usgs.gov \\ *corresponding author
}

Received: 21/03/2012 / Accepted: 05/05/2012

\begin{abstract}
Instrumental and historical seismicity in the Albacete province (External Prebetic Zone) has been scarcely recorded. However, major strike-slip faults showing NW-SE trending provide geomorphologic and paleoseismic evidence of recent tectonic activity (Late Pleistocene to Present). Moreover, these faults are consistently well oriented under the present stress tensor and therefore, they can trigger earthquakes of magnitude greater than M6, according to the lengths of surface ruptures and active segments recognized in fieldwork. Present landscape nearby the village of Hellin (SE of Albacete) is determined by the recent activity of the Pozohondo Fault (FPH), a NW-SE right-lateral fault with $90 \mathrm{~km}$ in length. In this study, we have calculated the Late Quaternary tectonic sliprate of the FPH from geomorphological, sedimentological, archaeoseimological, and paleoseismological approaches. All of these data suggest that the FPH runs with a minimum slip-rate of $0.1 \mathrm{~mm} / \mathrm{yr}$ during the last $100 \mathrm{kyrs}$ (Upper Pleistocene-Holocene). In addition, we have recognized the last two major paleoearthquakes associated to this fault. Magnitudes of these paleoearthquakes were gretarer than M6 and their recurrence intervals ranged from 6600 to $8600 \mathrm{yrs}$ for the seismic cycle of FPH. The last earthquake was dated between the 1st and 6th centuries, though two earthquakes could be interpreted in this wide time interval, one at the FPH
\end{abstract}


and other from a far field source. Results obtained here, suggest an increasing of the tectonic activity of the Pozohondo Fault during the last 10,000 yrs.

Keywords: Paleoseismology, Geomorphology, Quaternary, Prebetic, SE Spain

Resumen

A pesar de la escasa sismicidad instrumental e histórica en el Prebético Externo, que comprende la provincia de Albacete, existen tres grandes fallas con evidencias de actividad reciente y cuya orientación es compatible con el campo de esfuerzos activo. Estas fallas consisten en desgarres dextrorsos de orientación NO-SE cuya longitud de traza sobrepasa los $50 \mathrm{~km}$. Este trabajo se centra en el análisis del segmento Tobarra-Cordovilla de la Falla de Pozohondo (FPH) (90 km de longitud), mediante estudios paleosísmicos, geomorfológicos, sedimentológicos e incluso arqueosísmicos. De todos estos análisis es posible afirmar que dicha falla (FPH) presenta una tasa de actividad cuaternaria superior a $0,1 \mathrm{~mm} /$ año durante los últimos $100 \mathrm{ka}$ (Pleistoceno Superior-Holoceno). Además, se han descrito los últimos dos paleoterremotos asociados a este segmento con una tasa de recurrencia para magnitudes superior a M6 de 6600-8600 años, habiendo tenido lugar el último evento entre los siglos I y VI. Sin embargo, los datos no permiten fijar de forma más precisa dicho evento, e incluso es posible que hayan tenido lugar dos eventos diferenciados durante este periodo, uno relacionado con la FPH y el otro de origen de campo lejano. En cualquier caso, se evidencia un suave incremento en la actividad tectónica en la zona durante los últimos 10.000 años.

Palabras clave: Paleosismicidad, Geomorfología, Cuaternario, Prebético Externo, SE de España.

\section{Introduction}

The Prebetic units of the Betic Cordillera (SE of Spain) are in general featured by medium altitude topography (ca. 1000 m.a.s.1.), moderate size mountain ranges (e.g. Sierra de Alcaraz, $50 \mathrm{~km}$ range.) and Cenozoic lacustrine closed basins. Poor drainage lines were developed during Quaternary ages and endorheic basins are common. The lithology of these ranges comprises Jurassic limestone, Upper Miocene carbonate massifs ("Peñas Rubias") and marls. The Quaternary tectonic activity of the region is difficult to study due to the absence of tectonic markers typical of tectonic active areas. Furthermore, the low rate of instrumental seismicity, mainly with magnitude $<4.5$ for the instrumental seismic period, from 1980 to now, and the scarce historic seismicity, featured this area as quasi-stable for seismic hazard studies.

However, this paleoseismic evidence associated with surface faulting, as described in Calvo et al. (1998), Rodríguez-Pascua et al. (2000a) and Rodríguez-Pascua (2001), suggests that the Quaternary tectonic activity is recognizable properly in the geological record of the region. The pioneering work by García del Cura et al. (1979) described Quaternary faulting and ruptures affecting alluvial fans, determining the border of Quaternary basins and controlling drainage networks. Rodríguez-Pascua et al. (2008) described a coseismic rupture associated with the Tobarra-Cordovilla segment of the Pozohondo Fault (FPH). Besides, they suggested a previously unknown paleoearthquake, with magnitude greater than M6, probably during the Roman period. The authors included detailed mapping of the active fault segment, showing rupture surfaces and describing the geometry as a complex graben basin with back tilting. The morphology of the scarp shows a low erosion rate affecting the rupture sides and broken soils, suggesting a Holocene event.

Questions emerge in this context, absence of significant instrumental seismicity, scarce historical seismicity, active faults with episodic activity of moderate paleoearthquakes of magnitude M6 or greater. How could we parameterize active faults within this zone? Paleoseismology could give an answer for active faulting but tectonic geomorphology and sedimentology in active basins could do it also (Rodríguez-Pascua et al., 2009). Even archaeoseismic analysis could provide relevant information about fault events within the Prebetic Zone (RodríguezPascua et al., 2010).

Therefore, in this work we have studied the FPH from paleoseismology (trenches), lacustrine seismites and geomorphology, with the aim to estimate the tectonic slip-rate associated to this fault, to identify the last earthquake and consequently, its seismic cycle. We have also analysed the sedimentation rate of the Cordovilla Basin affected by this fault and we have incorporated information related with archaeoseismic evidence. Accordingly, we claim that the combination of these techniques is a good strategy for studying active tectonics within intraplate areas with low slip-rates $(\mathrm{SR}<0.1 \mathrm{~mm} / \mathrm{yr})$ and where only episodic fault events could be recorded by geology.

\section{Geological setting}

The Pozohondo Fault (FPH) belongs to the transfer zone of the Thrust Arc of Cazorla-Alcaraz-Hellín within the Prebetic External Zone (Jerez-Mir, 1973) (Fig. 1). 
This zone displays several right-lateral faults, being the master faults (a) Socovos, (b) Lietor and (c) Pozohondo (Rodríguez-Pascua, 2001; Rodríguez-Pascua et al., 2003). All of these faults are NW-SE trending and the superficial expression is larger than $50 \mathrm{~km}$ (Fig. 2). The Lietor and Socovos faults bound areas with E-W trending normal faults and well-developed Miocene lake basins, showing a relative high topography (ca 1000-2300 masl, Rodríguez-Pascua et al., 2003). In contrast, the Pozohondo Fault is the NE boundary of the transfer zone generating low topographic relief and poor development of lake basins during the Late Miocene. Rodríguez-Pascua et al. (2003) suggested that the activity of these dextral faults has not varied significantly since the Late Miocene.

Geomorphic evidence associated with FPH is well described at the middle part of the fault trace, located between Tobarra and Cordovilla villages (SE of Albacete) (Fig.2). Tectonic transtensive activity of the FPH since the Middle Pleistocene has generated the Quaternary lacustrine basin of Cordovilla (García del Cura et al., 1979; Rodríguez-Pascua et al., 2008). The basin is a depression located in a relatively large flat area. The Quaternary deposit of the Cordovilla Basin consists mainly of lacustrine and palustrine limestone sediments (freshwater tufa, micritic limestone, calcareous and organic-rich marlstone), paleosols, siliciclastic deposits and local gypsum beds (García del Cura et al., 1979). These deposits overlie Triassic, Jurassic and marine Miocene formations.

Evidence of the last coseismic rupture is still preserved because of the good exposure of the lacustrine tufa deposits. The landscape is flat with low topographic relief, and the fluvial network is characterised by poorly developed streams flowing SW to NE. A modern lake, dammed by a linear scarp related to a NW-SE transtensive strikeslip fault, is present in the northeastern part of the basin (Alboraj Lake) (Rodríguez-Pascua et al., 2008).

\section{Paleoseismology of the Pozohondo Fault}

The first report describing active tectonics for the FPH was the detailed description of the lake sedimentary infill of the Cordovilla Basin published by García del Cura el al. (1979). The relevance of this pioneering work was the relationship established between different stages for the Quaternary lacustrine deposition and the episodic fault activity of transtensive strike-slip faults with NW-SE trending. Later on, Rodríguez-Pascua et al. (2008) described the coseismic fault scarp associated with a paleoearthquake dated between 1 and 2 kyrs BP, by using geomorphic dating techniques of the diffusion equation and mass transport calibrated for this area (Pé-
rez-López et al., 2007). Besides, these authors estimated the maximum magnitude associated with this segment $6.1<\mathrm{M}<6.8$, applying the empirical relationship of Wells and Coppersmith (1994) for normal and strike-slip faults and by using the surface rupture and the coseismic displacement. The geometry of the basin fits well that of a complex graben with back-tilting and a central horst, according to the classification of McCalpin (2009) and the parameters measured by Rodríguez-Pascua et al. (2008).

Recently, Rodríguez-Pascua et al. (2009) estimated the slip-rate for the FPH since the Middle Pleistocene by using sedimentation rates of the Cordovilla Basin. They describe three different stages: (1) first stage $<700$ kyrs, (2) medium stage dated between 400 and 100 kyrs and (3) present stage, from 100 kyrs up to now. Ages were obtained from U-Th dating of tufa deposits and the study of the different sedimentation rates (Rodríguez-Pascua et al., 2009). Tectonic slip rates of $0.05 \mathrm{~mm} / \mathrm{yr}$ were obtained from Middle Pleistocene to Upper Pleistocene and $0.09 \mathrm{~mm} / \mathrm{yr}$ from Upper Pleistocene to recent. This means that the FPH accelerated during the last 100 years with a recurrence period of $10 \mathrm{kyrs}$ for earthquakes with magnitude $6<\mathrm{M}<6.5$.

In this work we discuss the results obtained from trenching at the youngest part of the Tobarra - Cordovilla segment of the FPH (Fig.3). Thermal anomalies are described in the surroundings of the segment at the tip points, "La Pestosa" (NW of the segment) and "Los Baños de Santa Quiteria" (SE of the segment) (Fig. 2), both of them used as thermal springs during the Roman Period $\left(1^{\text {st }}\right.$ century AD) and even in modern ages (19th Century). The activity of this segment produced a small closed-lake (125 $\mathrm{m}$ of diameter) associated with the antithetic fault of the Cordovilla graben, this resulting in a poorly drained endorheic basin (Fig. 3 and 4A). The younger deposits affected by the segment scarp are formed of Late Pleistocene lacustrine deposits and Holocene soils (Fig. 4).

The trench site (Fig. 3, T-mark) was chosen according to the age of the scarp, soil development, mass movement of soft deposits and the higher sedimentation rate associated with the scarp. The trench outcrop shows recent open cracks (Fig. 4B) and evidence of fresh morphology associated with coseismic movement (vertical and horizontal displacement). Hence, we assume that this zone could be the scarp generated by the last paleoearthquake and it was preserved due to the arid climatic conditions and limited agricultural activity (Fig. 4C). The length of the scarp is $9.3 \mathrm{~km}$ (Rodríguez-Pascua et al., 2008) and the average height and maximum height of the scarp are 0.6 and 1.9 respectively. Figure 5 shows the tectonic style of the Cordovilla basin, according to the strike-slip tectonic regime 


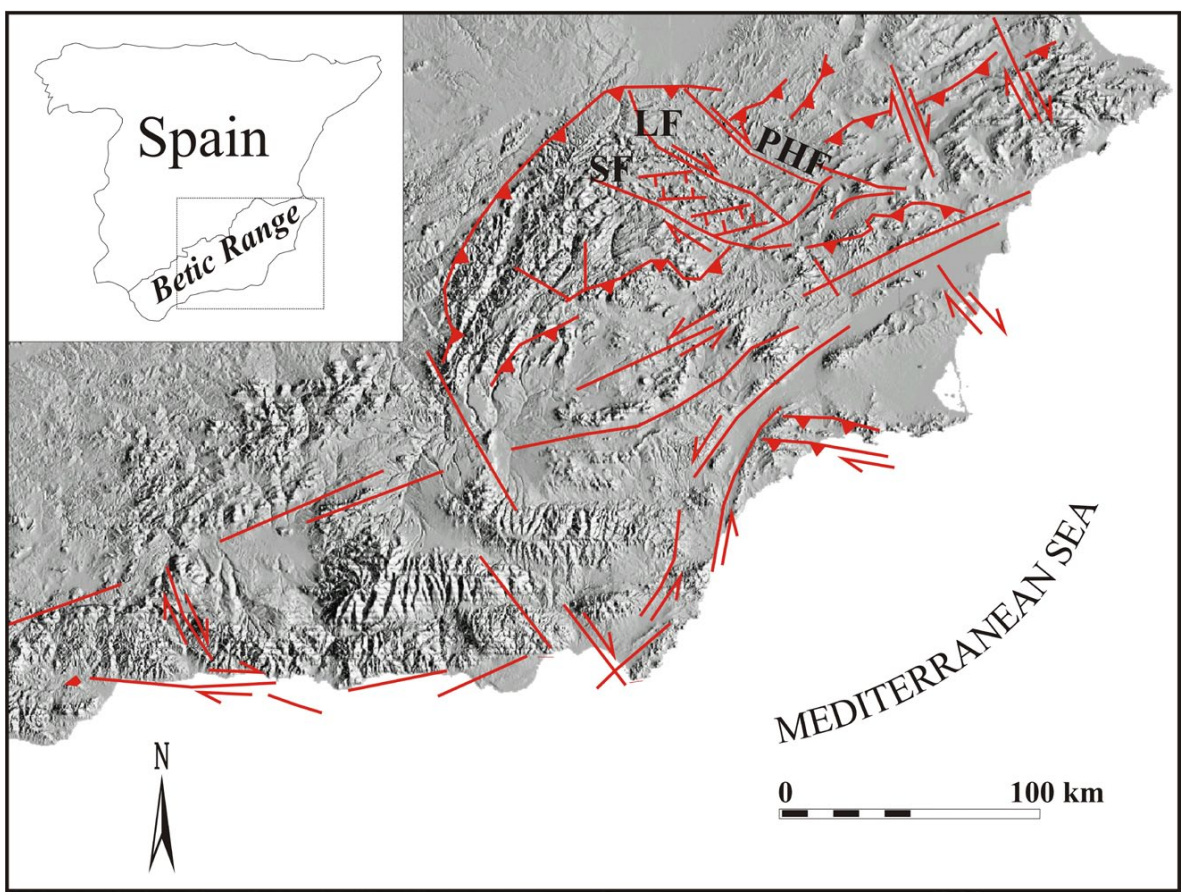

Fig. 1.- Geographic location of the transfer fault zone in the Cazorla-Alcaraz-Hellin Arc, constituted by three faults: Socovos (FS); Lietor (FL) and Pozohondo (FPH).

Fig. 1.- Localización geográfica de la zona de transferencia de fallas del arco estructural Cazorla-Alcaraz-Hellín, mostrando las principales estructuras: Falla de Socovos (FS); Falla de Lietor (FL) y Falla de Pozohondo (FPH).

Fig. 2.- Geological sketch of the Cordovilla Segment in the Pozohondo Fault (Pleistocene-Holocene) (modified after Jerez-Mir, 1980).

Fig. 2.- Esquema geológico del segmento activo de Cordovilla de la Falla de Pozohondo, de edad Pleistoceno-Holoceno (Modificado de Jerez-Mir, 1980).

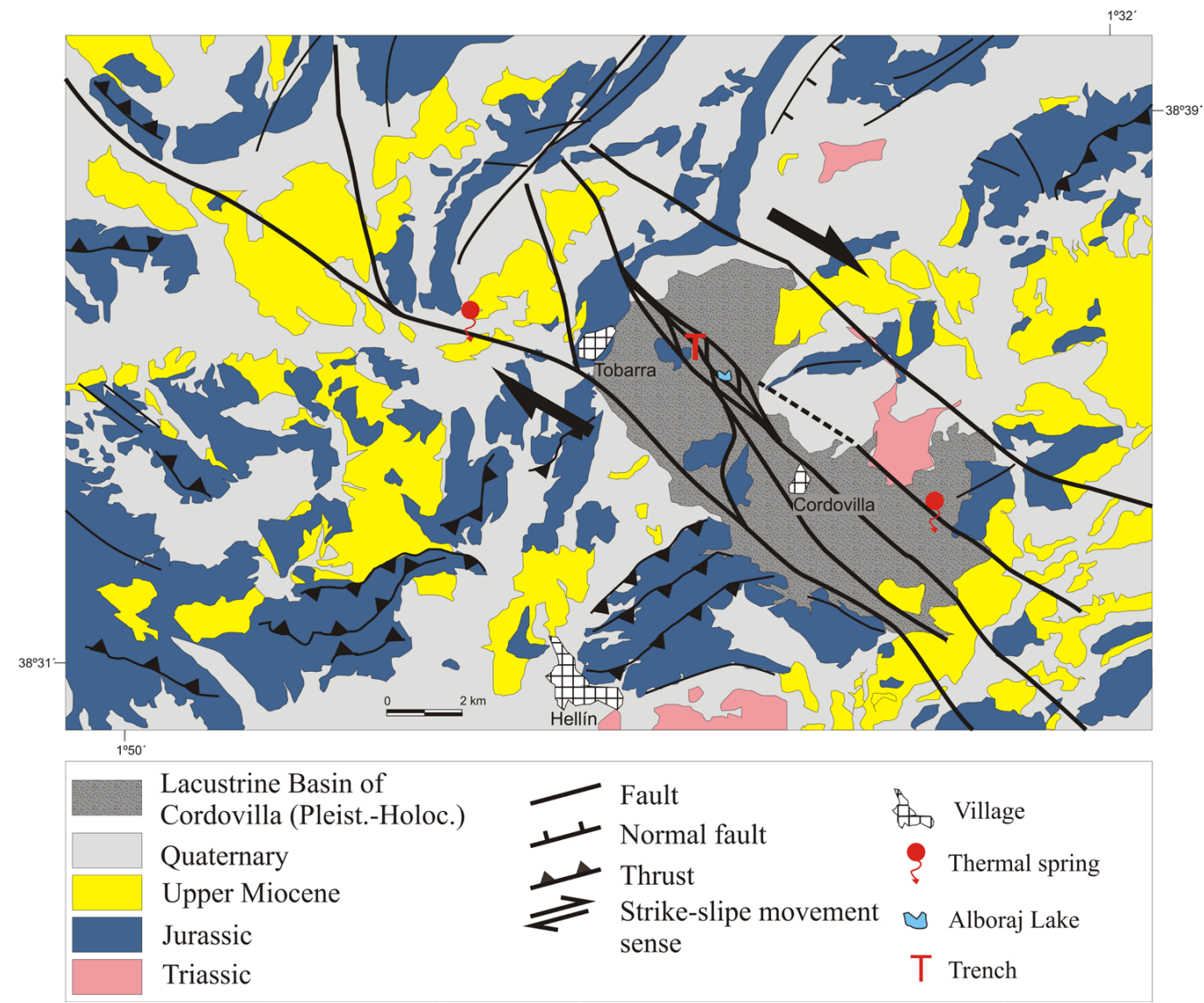

widely accepted for this zone (i.e. Rodríguez-Pascua and de Vicente, 2001). In this context, pull-apart basins determine the drainage network and closed lakes. The lacustrine sedimentation rates are higher than expected for a "normal" lake without tectonic uplift of the surroundings.
However, vertical movement can be seen from the $1.6 \mathrm{~m}$ vertical scarp in Figs 4B, 4C

The trench is NE-trending, $11 \mathrm{~m}$ long and $3 \mathrm{~m}$ wide, showing normal faulting throw with the foot wall towards SW and the hanging wall towards NE (Fig. 6). 
The last paleoearthquake also produced reverse antithetic faulting associated with the main movement of normal faulting (See Fig. 7, D3-D1). This reverse faulting is commonly associated with surface ruptures of normal faulting, for example during the Acambay earthquake of 1912 (México, seismic intensity X MSK, Urbina and Camacho, 1913). Besides, McCalpin (2009) described this reverse antithetic faulting as reverse secondary faulting for normal faults from different trenches performed at Wyoming, USA.

\section{Trench log description of the FPH}

The lithology of the materials affected by the FPH exhibits lacustrine deposits overlying re-elaborated Triassic gypsum. The last paleoearthquake generated open cracks filled with organic matter, gastropods, and wood and vegetal remains. The organic matter was dated by radiocarbon techniques (Fig. 7: B6- B8 y Fig. 8: C5-C8). Calibrated radiocarbon ages were obtained by using the Fairbanks 0805 online calculator (http://radiocarbon. ldeo.columbia.edu/research/radcarbcal.htm), and the

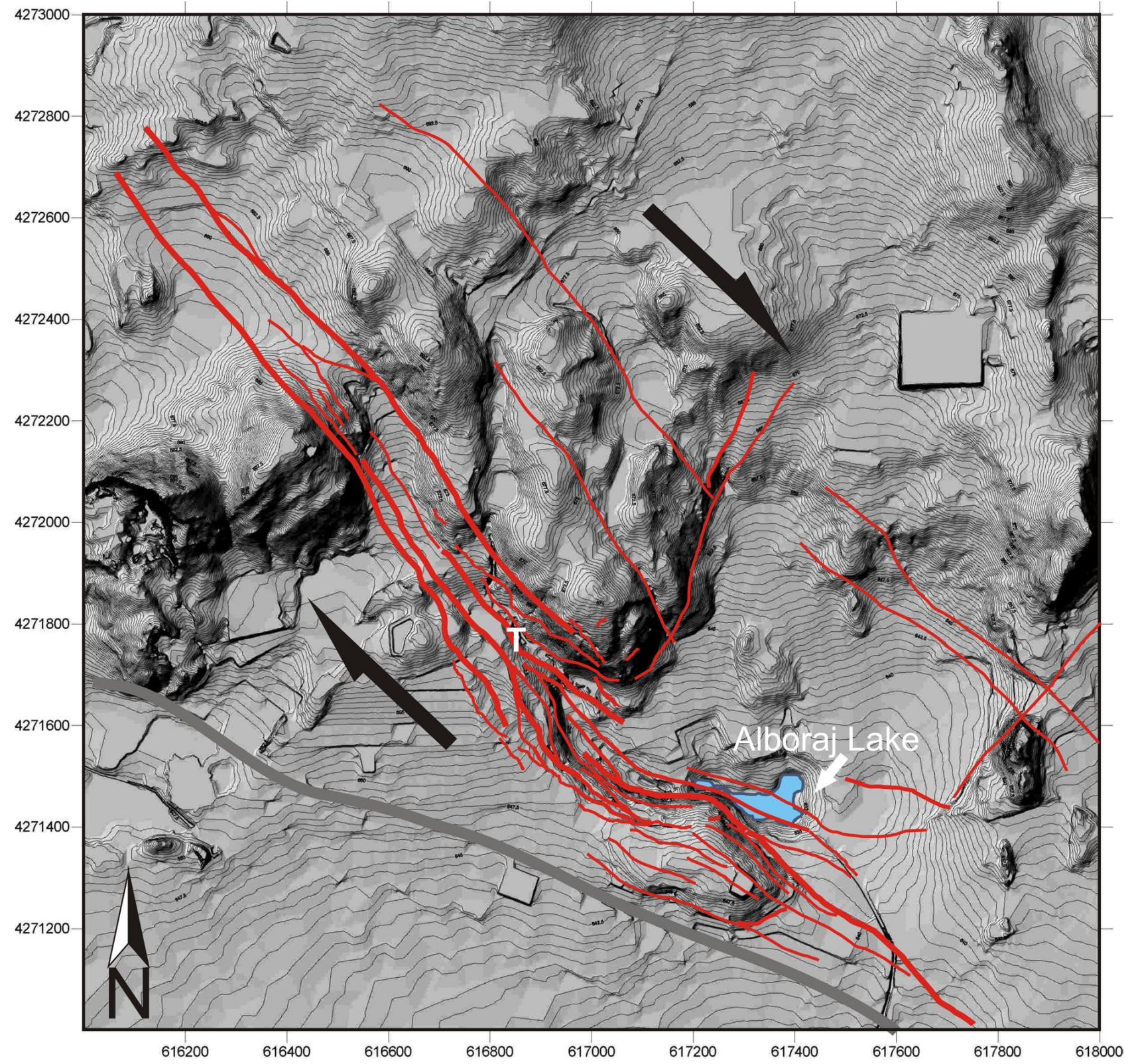

Fig. 3.- Detailed topography of high resolution (50 cm pixel size) of the Alboraj lake and surroundings. T-mark indicates the site of the trench performed in this work. Red lines are main faults (bold lines) and secondary faults mapped by GPS.

Fig. 3.- Microtopografía ( $50 \mathrm{~cm}$ de resolución) de la zona de la laguna de Alboraj. Las trazas representan las grietas de la banda de deformación de la Falla de Pozohondo a su paso por la Cuenca Cuaternaria de Cordovilla. La letra " $T$ " marca la posición de la trinchera realizada. Las líneas rojas marcan las fallas principales (trazo grueso) y las fracturas secundarias. 

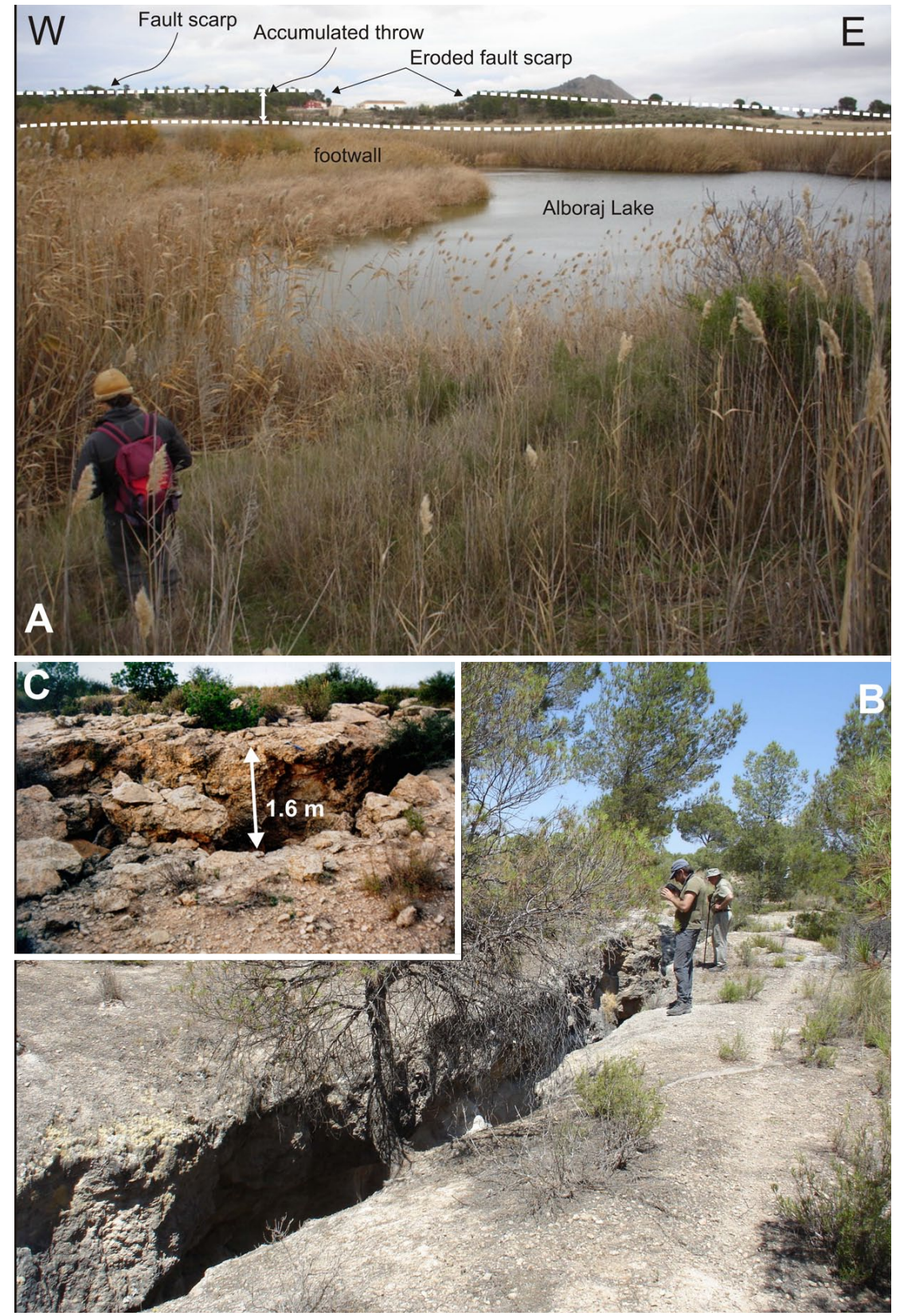

Fig. 4.- A) Photograph of the Alboraj Lake and the accumulated vertical throw of the FPH. B) Detailed view of open cracks associated with the main scarp of FPH. C). Accumulated vertical throw affecting Quaternary lacustrine limestones and probably related with the paleoevents described inhere.

Fig. 4.- A) Esquema fotográfico de la Laguna de Alboraj, en el que se puede observar al fondo el salto acumulado de la Falla de Pozohondo en este punto. B) Grietas en el entorno de la Laguna de Alboraj. C) Salto de falla acumulado sobre calizas lacustres cuaternarias de los dos últimos terremotos. radiocarbon ages are also included in the text (Table 1) (Fairbanks et al., 2005). The detailed lithological units are described as follows (Fig.7):

Unit T1 and T2: The lowest units correspond with Triassic (Keuper) red claystones (T1 is darker than $\mathrm{T} 2$ ). These claystones appears fractured and folded, and with re-crystallization of gypsum.

Unit P1: A fluvial-lacustrine channel $50 \mathrm{~cm}$ thick shows an erosive base affecting the $\mathrm{T} 1$ and $\mathrm{T} 2$ units and is filled by reworked oncolite and tufa fragments.

Unit P2: This unit (60 cm of thickness) is composed of lacustrine limestone with horizontal bedding, and with scarce oncolites.
Unit H1: Conglomerate of lacustrine and tufa blocks with sandy matrix.

Unit H2: Fluvio-lacustrine desposits with horizontal stratification and bioturbation. This stratigraphic sequence transforms to lacustrine facies upwards. Horizontally-bedded, bioturbated fluvio-lacustrine deposits composed by sandstones, passing upwards into lake facies (limestones).

Unit H3: Stratified lacustrine limestone fragments with dispersed oncolites of centimetric size.

Unit H4: Detritic lacustrine sediment with matrix of limestone and well stratified. 
Unit H5: Detritic wedge of conglomerate of carbonates and sandy matrix, formed by mobilised carbonatic sediments.

Unit S1: Paleosoil of siliciclastic sands with carbonate clasts and rich in organic matter.

Unit S2: Sediment infilled crack rich in organic matter with gastropods.

Unit S3: Recent soil.

\section{Paleoseismic interpretation of the log trench}

We have interpreted two paleoevents from the log of the trench of FPH, and therefore, we can estimate the seismic cycle of the Tobarra-Cordovilla segment of the FPH during the Holocene.

Paleoevent 1 . This is the last paleoearthquake associated with this segment and shows a net throw of $1.2 \mathrm{~m}$. The fault plane is oriented to $\mathrm{N} 145^{\circ} / 65^{\circ} \mathrm{NE}$ (Fig. 7: B8-C7D7 and Fig. 8: B7-C7-D7). This plane exhibits striation with $88^{\circ}$ clockwise (right-hand rule). We have measured several (19) slickensides and the Right Dihedral Analysis (Angelier and Mechler, 1977), indicating a strain field of normal faulting with lateral component (Fig. 7). This strain field agrees with the stress and strain active fields described by Rodríguez-Pascua and de Vicente (2001). The magnitude estimation by using the Wells and Cop- persmith (1994) relationship for the maximum throw of normal faulting indicates a magnitude ranging between $6.5<\mathrm{M}<6.8$. Radiocarbon ages of AMS for this event lie between $1950 \mathrm{BP}( \pm 30), 1630 \mathrm{BP}( \pm 30)$ and $1410 \mathrm{BP}$ $( \pm 35)$ (Table 1) (see figure 7 and 8 for sample location). Therefore, the last earthquake occurred between the year 58 and $640 \mathrm{AD}\left(1^{\text {st }}\right.$ and $7^{\text {th }}$ centuries, calendric ages). Calibrated ages appear in Table 1, according to Fairbanks et al. (2005).

Paleoevent 2. The previous event to the last earthquake was identified from a clastic wedge fossilized by a paleosoil preserved at the hanging wall deposits (Fig. 8: C5C7 and Fig. 9: C5-C7). The thickness of the wedge is $80 \mathrm{~cm}$. We have used this thickness as a maximum vertical throw for normal faulting and according to Wells and Coppersmith (1994) the maximum magnitude is $6.3<\mathrm{M}<6.7$, very similar to the last event. Radiocarbon calibrating age for this paleoevent is younger than 7.380 BP $( \pm 90)$ (Table 1), obtained from a small piece of wood (Fig. 7: D3) in $\mathrm{H} 2$. $\mathrm{H} 5$ unit is on top and eroding $\mathrm{H} 2$ unit, and therefore E2 is constrained by this radiocarbon age. Calibrated ages appear in Table 1, according to Fairbanks et al. (2005).

The oldest paleoevent could be recognized by the angular discordance affecting the oldest lacustrine depos-

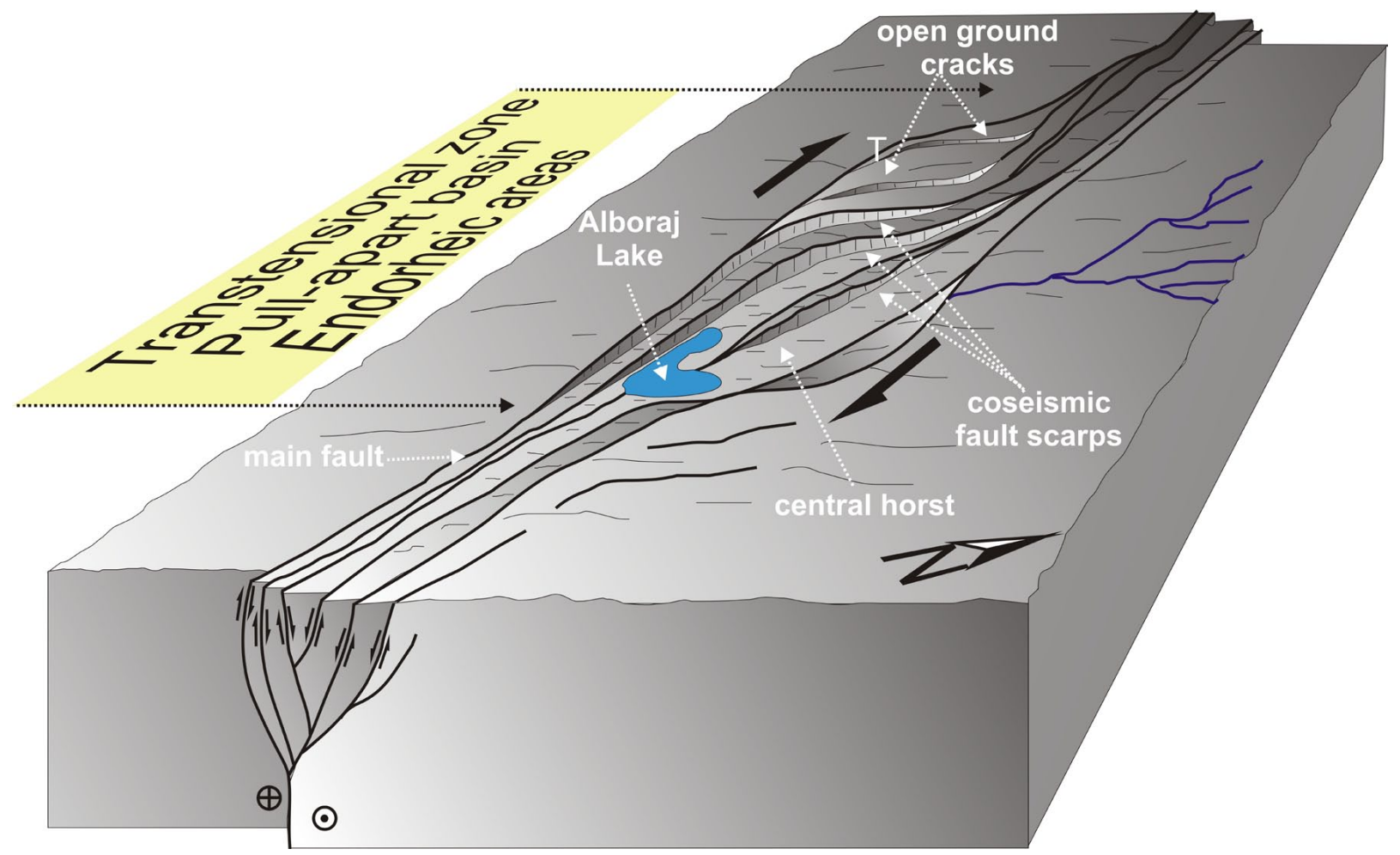

Fig. 5.- Block diagram of the strike-slip style and pull-apart development within the area. T-mark indicates the site of the trench performed in this work.

Fig. 5. Esquema de la zona transtensiva de la falla de Pozohondo que genera una cuenca tipo "pull-apart" en la zona de la laguna de Alboraj. La letra " $T$ " marca la posición de la trinchera realizada. 


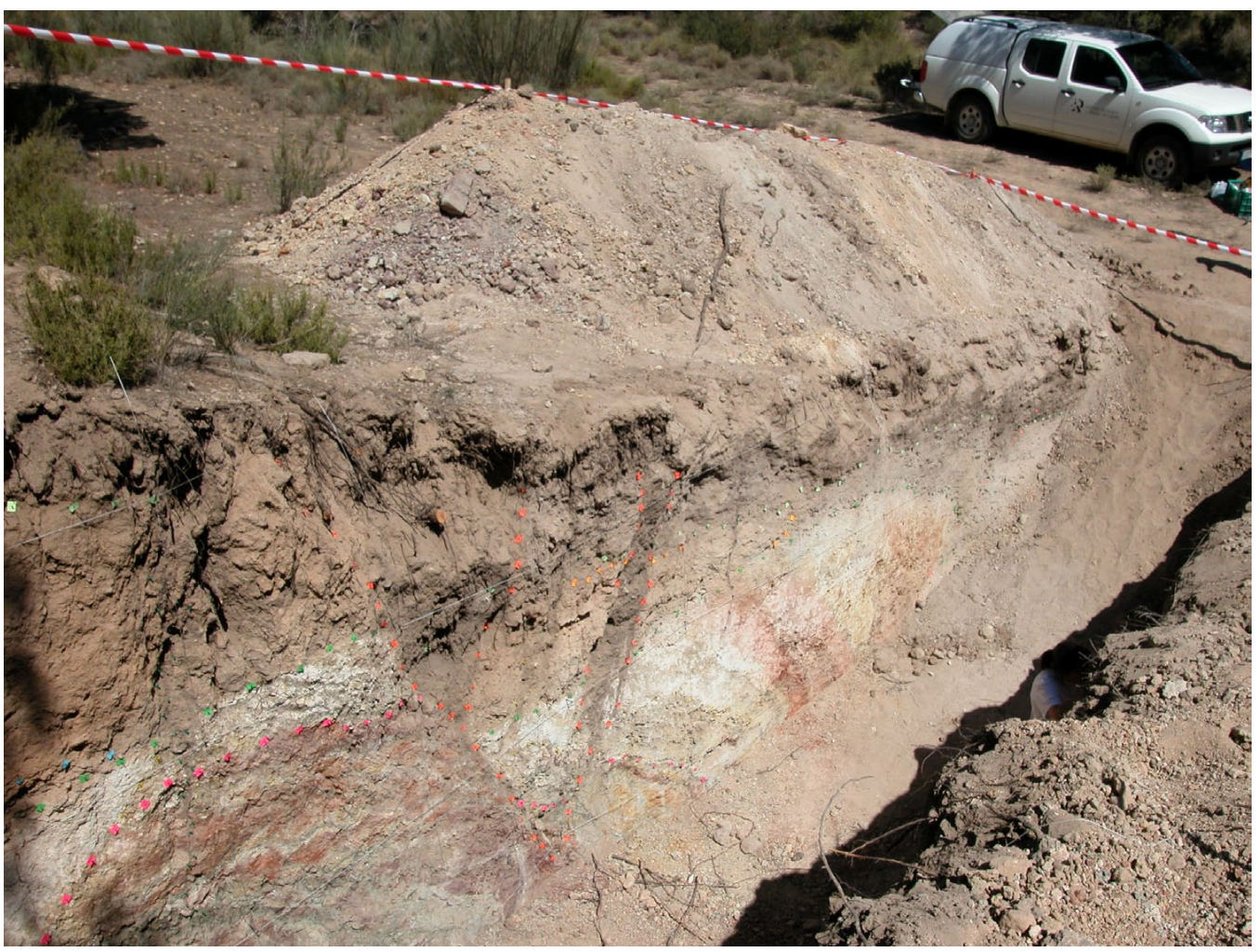

Fig. 6.- Trenching on the Pozohondo Fault, Cordovilla segment in the vicinity of the Alboraj Lake. Fig. 6.- Trinchera sobre la FPH, segmento activo de Cordovilla, cerca de la Laguna de Alboraj.

Fig. 7.- Trench log of the Pozohondo Fault Segment of Cordovilla, South-side. Dates correspond to radiocarbon dating samples (Table 1) and right dihedral diagram of structural data obtained from de main fault plane (red indicates compression and blue extension). Net-size of $1 \mathrm{~m}^{2}$.

Fig. 7.- Log de la trinchera sobre la cara sur. Las fechas corresponden a dataciones de radiocarbono (Tabla 1) y diagrama de diedros rectos de los datos estructurales tomados en el plano de falla principal (rojo indica compresión y azul extensión). La malla tiene un tamaño de $1 \mathrm{~m}$ x $1 \mathrm{~m}$.

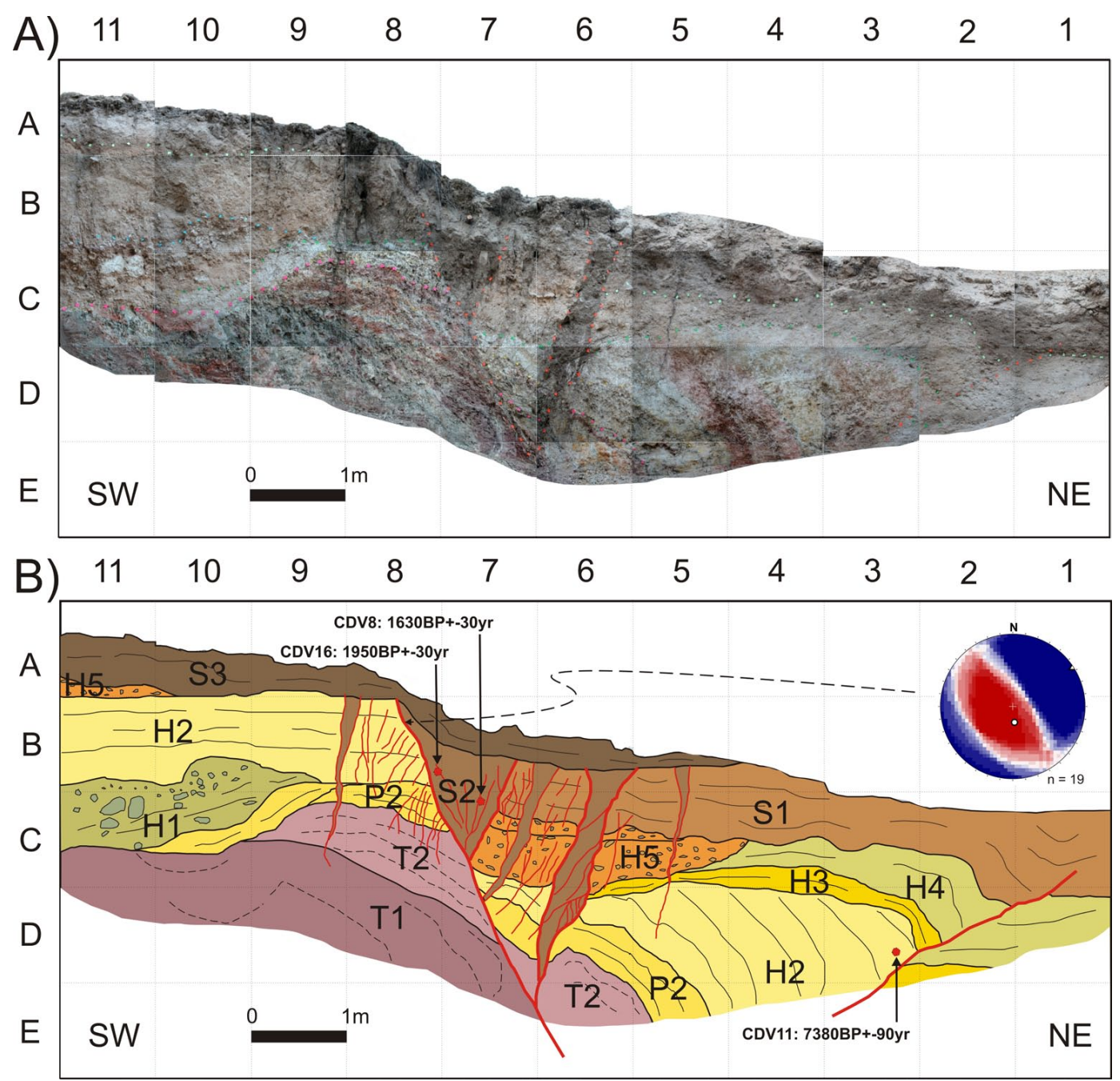


its. The lacustrine sequence was deformed by a drag fold possible related with a coseismic vertical throw, and then being eroded and fossilized by a new lacustrine sequence. However, this layer arrangement does not allow estimating the minimum vertical coseismic throw because of no reference layer can be recognized. Radiocarbon age for this paleoevent is younger than 26,000 BP $( \pm 170)$ (Table $1)$, according to the oldest lacustrine deposits described into the trench (Fig. 8: C11).

\section{Seismites in the Alboraj Lake sedimentary record}

A number of 35 samples were collected from cores drilled in the Alboraj Lake with the aim to recognise seismites in the recent sedimentary record of the lake. The core is $50 \mathrm{~cm}$ in thick, and the time interval represented includes the last 3000 years of record (Vegas et al., 2012). Figure 9 shows two of these cores, SA-22 and SA-25, located at the deepest zone of the lake ( $6 \mathrm{~m}$ depth). In both cores seismites can be recognized, namely fault-gradedbeds (e.g. Seilacher, 1969; Rodríguez-Pascua, 2001). Radiocarbon ages for both structures are 1434 BP $( \pm 30)$ for SA-22 and $1608 \mathrm{BP}( \pm 30)$ for SA-25 (Table 1). Cali- brated ages appear in Table 1, according to Fairbanks et al. (2005). The uppermost part of the lake carbonate sequence does not show any kind of seismic or gravitational deformation. Furthermore, both seismites are bounded by non-deformed layers. Radiocarbon ages are in agreement with those obtained for paleoearthquakes in the trench.

\section{Archaeoseismological evidence}

In the vicinity of the Alboraj Lake and the Pozohondo Fault, there are the outstanding archaeological remains of "El Tolmo de Minateda". Rodríguez-Pascua et al. (2010) demonstrated the occurrence of a paleoseismic event dated between the centuries $1^{\text {st }} \mathrm{AD}$ and IV AD (Roman cultural period of the Iberian Peninsula), by applying archaeoseismic techniques. These techniques focussed on the partial oriented collapse of the defensive wall, and also the fall of the watch tower and abandonment of the city related with both collapses. Furthermore, rock fallings and city collapsed related with different potential paleoseismic events dated during the Visigoth Cultural period ( $7^{\text {th }}$ AD Century), other during the Islamic Cultural Period ( $9^{\text {th }} \mathrm{AD}$ century) and the effects of the great earth-

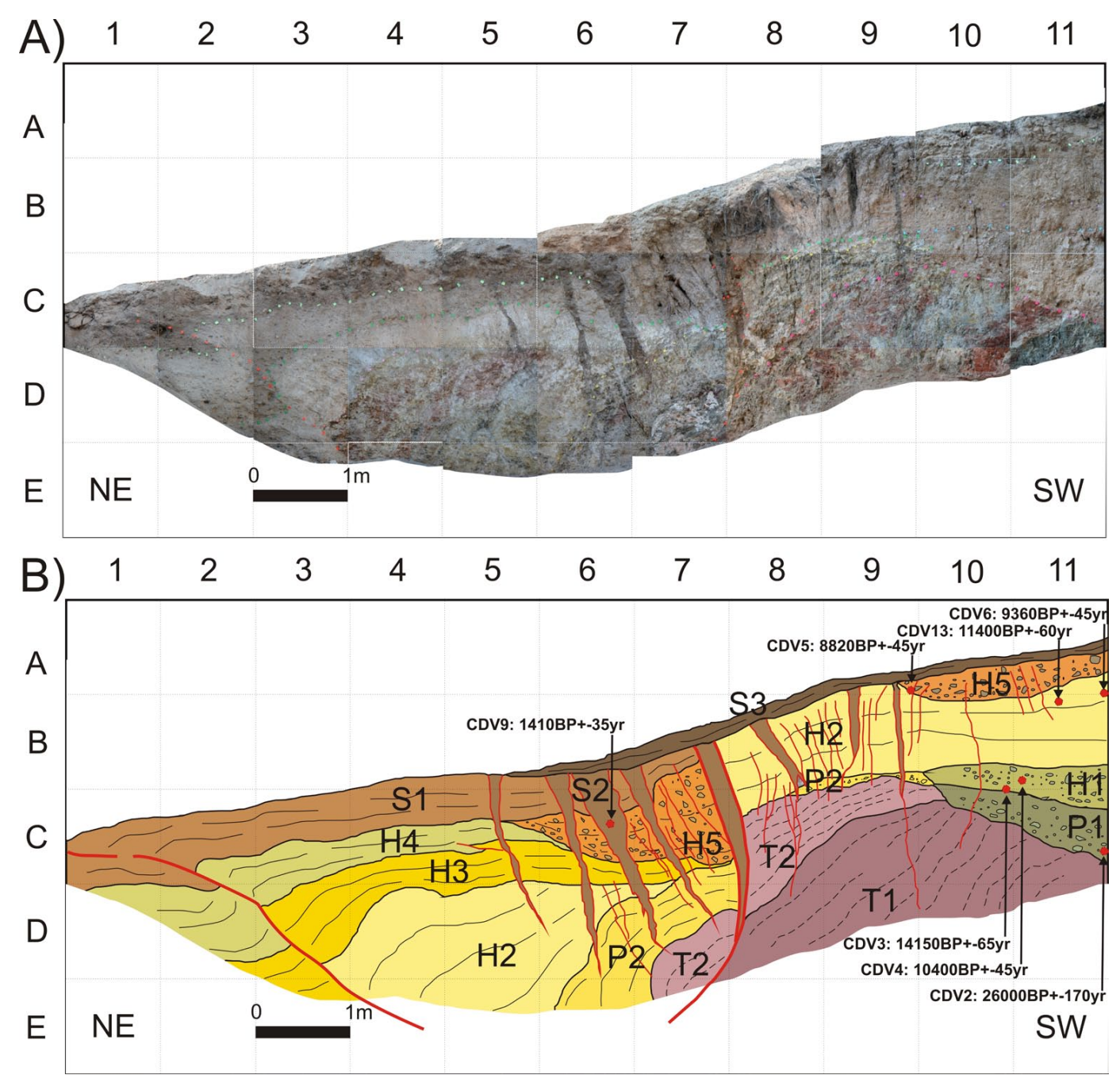

Fig. 8.- Trench $\log$ of the Pozohondo Fault Segment of Cordovilla, North-side. Dates correspond to radiocarbon dating samples (Table 1). Net-size of $1 \mathrm{~m}^{2}$.

Fig. 8.- Log de la trinchera sobre la cara norte. Las fechas corresponden a dataciones de radiocarbono. La malla tiene un tamaño de $1 \mathrm{~m} \times 1 \mathrm{~m}$. 


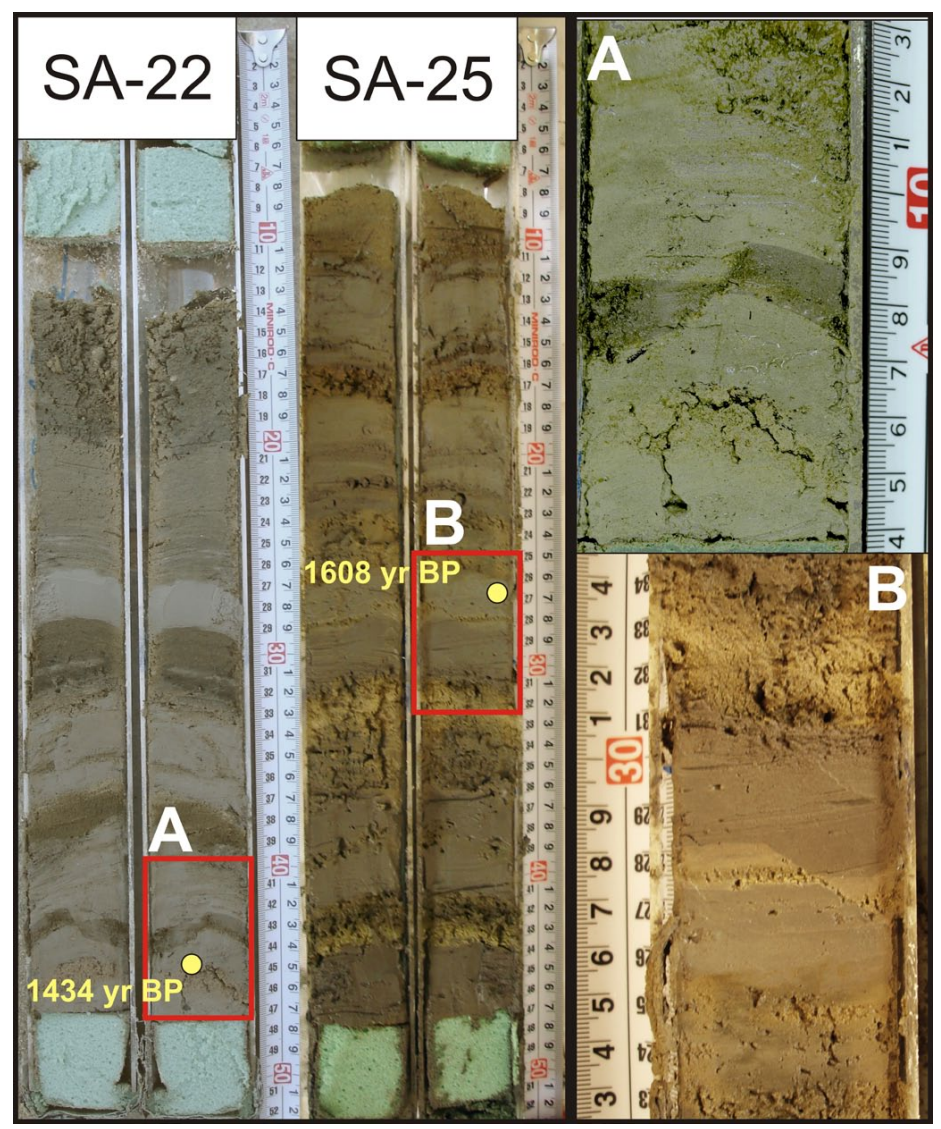

Fig. 9.- Lacustrine cores SA-22 and SA-25, obtained at a depth of $4 \mathrm{~m}$ and located at the depocenter of the lake. A and $\mathrm{B}$ boxes indicate fault-graded-beds with radiocarbon ages of $1434 \mathrm{BP}$ and $1608 \mathrm{BP}$. See Table 1 for ages.

Fig. 9.- Sondeos SA-22 y SA-25 realizados a $4 \mathrm{~m}$ de profundidad de lámina de agua (50 $\mathrm{cm}$ de registro sedimentario) cerca del depocentro de la laguna de Alboraj (6 m máximo). "Fault graded beds" localizados en estos sondeos y correlacionables entre sí: A) localizado en el sondeo SA-22 y datado a muro en 1434 años BP (Tabla I); B) estructura localizada en el sondeo SA-25 datada a techo en 1608 años BP (Tabla I).
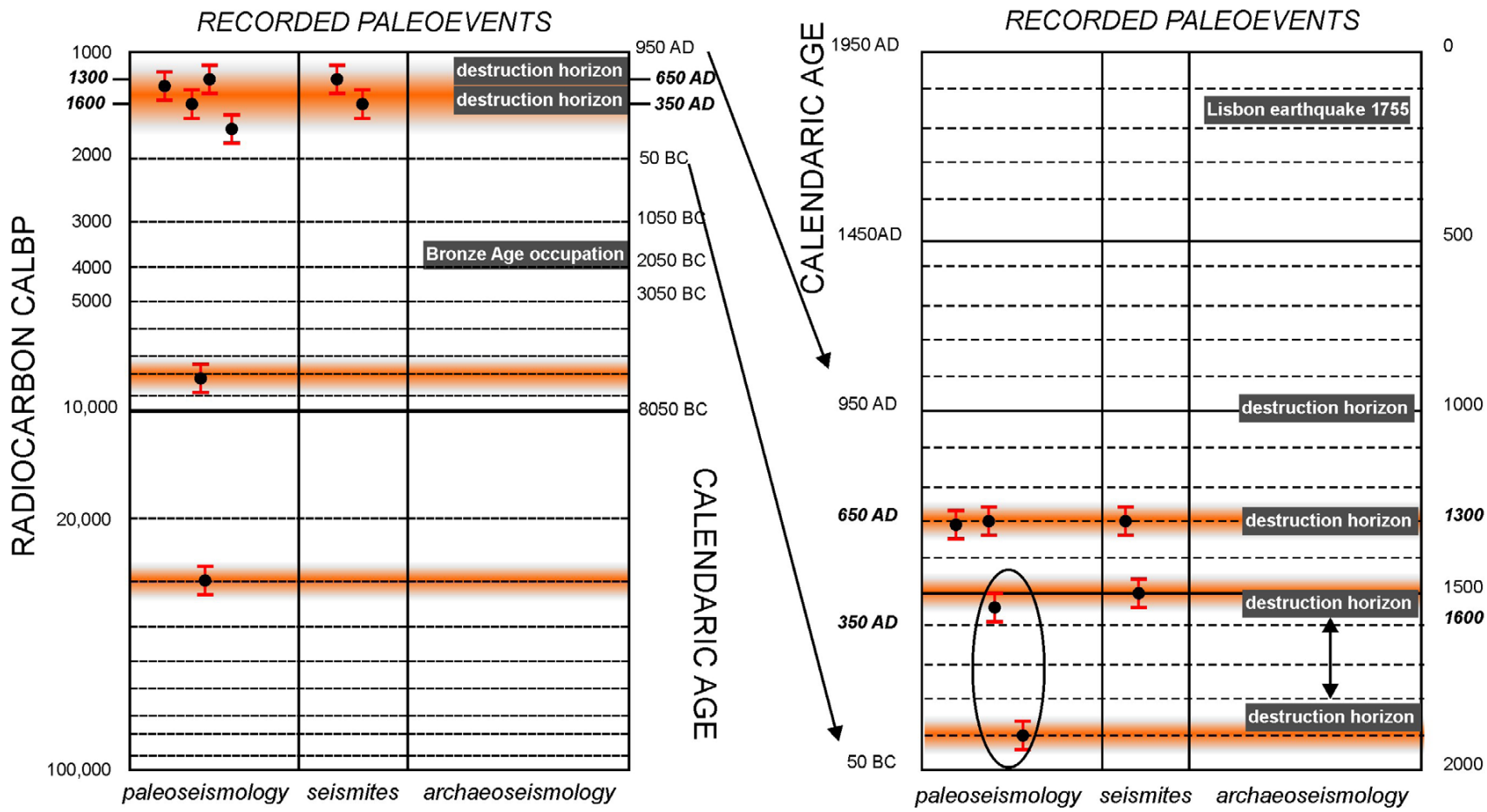

Fig. 10.- (Left): Recorded paleoevents within the trench (paleoseismology), seismites interpreted from the cores SA-22 and SA-25 and archaeoseismic evidence in the "El Tolmo de Minateda" site (located $7 \mathrm{~km}$ ESE of Hellín). Vertical axis is in logarithmic units. (Right): Detailed agegraph for the younger events. See the discussion section for further explanation.

Fig. 10.- (Izquierda): Registro en el tiempo de los paleoeventos interpretados y su posible correlación entre los datos paleosísmicos, de las sismitas y evidencias paleosísmicas en el yacimiento arqueológico de "El Tolmo de Minateda" (localizado a 7 km al este-sureste de Hellín). Eje vertical en escala logarítmica. (Derecha): Ampliación y detalle de la distribución en el tiempo de los eventos más recientes. Mirar la sección de discusión para una descripción más detallada. 
quake of Lisbon of the $1^{\text {st }}$ of November, 1755. Figure 10 shows the main paleoseismic events recognized at the archaeological site of "El Tolmo de Minateda", according to Rodríguez-Pascua et al. (2010).

\section{Discussion}

Figure 10 (left) shows the distribution of the main paleoevents recognized at different kind of studies: data from the trench (paleoseismology), data from the lacustrine cores (seismites) and archaeoseismic record. Red bars indicate potential paleoearthquakes interpreted from these levels. The first event (E0) has been dated younger than 26,000 yrs BP, a paleoevent described from the discordance and tilting of the Late Pleistocene lacustrine materials (Figs. 7 and 8). A second event (E1) is interpreted from the clastic wedge described at the trench log (Figs. 7 and 8) and directly assigned to the FPH. Finally, a third paleoevent (E2) is recognized from the fresh scarp of the trench, the fault plane affecting soils and could be dated between the Roman and the Visigothic cultural period of the Iberian Peninsula. At this point, the coincidence between paleoseismic evidence on-fault and seismites off-fault, plus the archaeoseismic record suggests a paleoevent with a magnitude ranging between 6.3 and 6.8, according to the Wells and Coppersmith (1994) empirical relationship for normal faulting and vertical throw of $60-80 \mathrm{~cm}$.

A detailed view (Fig. 10, right) of the time period between modern ages (1950 AD) and the Roman Cultural Period (age $50 \mathrm{BC}$ ), indicates the possibility that two earthquakes have affected the archaeological site. Since only one coseismic event could be recognized from the trench (E2), we assume that the FPH was responsible for the event E2 and the other event (only recorded by archaeoseismicity) could be triggered from another fault, as a far-field event. Unfortunately, there is no evidence to assign which one was triggered from the FPH and which one by far-field, according to the radiocarbon ages. Therefore, the recurrence interval of the FPH for the last two events E1 and E2 lies between 6000 and 5000 yrs, and for earthquakes with magnitudes between $6.3<\mathrm{M}<6.8$. The ellipse of the figure 10 (right), encircles two radiocarbon data that could be only one but showing different values either by contamination during the extraction of the sample, or as re-deposited gastropods sells.

The tectonic slip-rate for the FPH ranges between 0.1 and $0.06 \mathrm{~mm} / \mathrm{yr}$, according to the recurrence time for these size-earthquakes during the Holocene (Fig. 11). Rodríguez-Pascua et al. (2010) estimated a stratigraphic and paleoseismic slip-rate for this transfer zone between 0.05

\begin{tabular}{|c|c|c|c|c|c|}
\hline Data & $\begin{array}{c}\text { Radiocarbon } \\
\text { yrs BP }\end{array}$ & error & $\begin{array}{c}\text { CAL } \\
\text { BP }\end{array}$ & error & $\begin{array}{c}\text { Age } \\
(\mathrm{AD} / \mathrm{BC})\end{array}$ \\
\hline paleosei & 1410 & 35 & 1310 & 21 & $640 \mathrm{AD}$ \\
\hline paleosei & 1440 & 30 & 1328 & 23 & $622 \mathrm{AD}$ \\
\hline paleosei & 1630 & 30 & 1523 & 34 & $427 \mathrm{AD}$ \\
\hline paleosei & 1950 & 30 & 1892 & 31 & $058 \mathrm{AD}$ \\
\hline paleosei & 7380 & 90 & 8200 & 100 & $6250 \mathrm{BC}$ \\
\hline paleosei & 26000 & 170 & 31232 & 229 & \\
\hline seismi & 1434 & 30 & 1322 & 21 & $628 \mathrm{AD}$ \\
\hline seismi & 1608 & 30 & 1500 & 41 & $450 \mathrm{AD}$ \\
\hline
\end{tabular}

Table 1.- Radiocarbon ages in years with the standard deviation in years as well. Calibrated ages were obtained from Fairbanks et al. (2005) calibration curves. "Paleosei" indicate samples from the trench (Figs. 7, 8) and "seismi" samples from the cores SA-22 and SA-25.

Tabla 1.-. Edades de radiocarbono en años y error asociado a partir de la desviación estándar. La edades calibradas se obtuvieron a partir de la curva de calibración de Fairbanks et al. (2005). "Paleosei" indica las muestras medidas en al trinchera (Figs 7, 8), mientras que "seismi" se indica para las muestras el sondeo SA-22 y SA-25.

and $0.09 \mathrm{~mm} / \mathrm{yr}$. In this case, the slip-rate for steady-data (trenches) and long-term data (stratigraphy) are in agreement; fit well a reasonable constant value for intraplate areas during the last 500,000 yrs. Moreover, Rodríguez-Pascua et al. (2000b) estimated the tectonic vertical slip-rate from the lacustrine infilling of Upper Miocene basins, according to the pull-apart style. These authors pointed out a slip-rate of $0.05 \mathrm{~mm} / \mathrm{yr}$ (Fig.11). Besides, we could estimate an upper limit for the tectonic slip-rate for a very long term period, namely for the Neotectonic period (Late Miocene, Rodríguez-Pascua and de Vicente, 2001). During this period the total slip-rate for the whole Prebetic Zone is assumed close to $0.5 \mathrm{~mm} / \mathrm{yr}$. This value is obtained from the highest Upper Miocene topography (Sierra del Segura, 1993 masl) from the last $5 \mathrm{Ma}$. We interpreted this value as a good proxy to evaluate the quality of the slip-rates estimated for the FPH in relation to the time period of measurement.

\section{Conclusions}

The Pozohondo fault (strike-slip transtensional fault) shows an active segment where paleoseismic, stratigraphic and archeoseismic evidence can be obtained for the Late Quaternary history of the region.

Paleoseismic features provide evidence for two Holocene paleoevents, E1 (ca 8000 CALBP) and E2 (ca centuries I-VI AD). The coseismic vertical throw ranges between 0.6 and $0.8 \mathrm{~cm}$, with an accumulated vertical throw of $1.8 \mathrm{~m}$ for the Holocene. Therefore, the magni- 


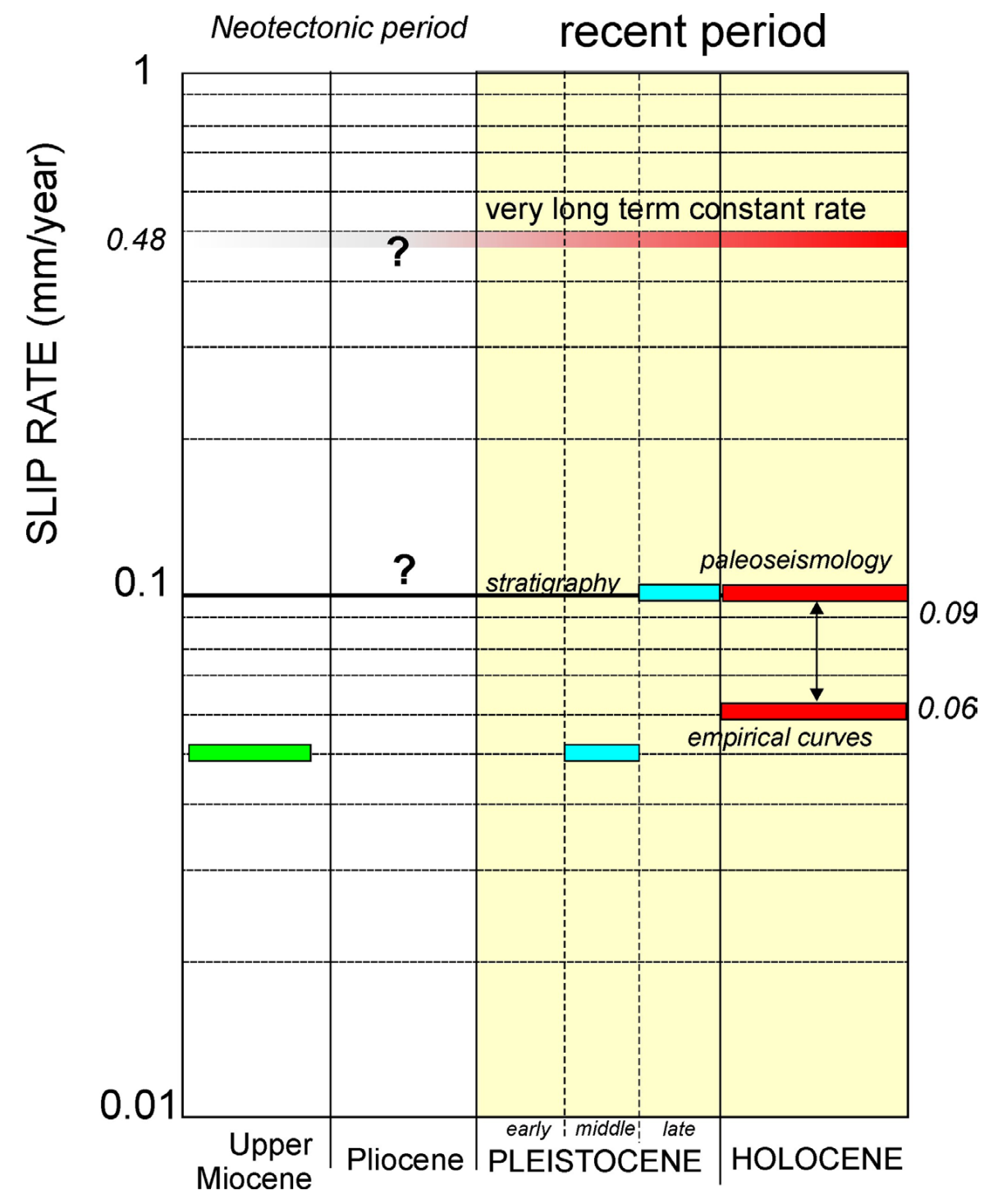

Fig. 11.- Tectonic slip-rate in $\mathrm{mm} / \mathrm{yr}$ for the FPH and the Prebetic Range (very long-term constant rate). Values of FPH were obtained from the recurrence of the paleoevents 1 and 2 for $6<\mathrm{M}<6.5$ the empirical curve of Slemons (1982). Vertical axis is in logarithmic units. See the discussion section for further explanation.

Fig. 11.- Tasa de deformación tectónica de la FPH en mm/año y deformación tectónica vertical del Prebético (very long-term constan rate). Los datos para FPH se obtuvieron a partir de la recurrencia de los paleoeventos 1 y 2, para magnitudes $6<\mathrm{M}<6,5$ y la curva empírica sugerida por Slemons (1982). Para una explicación más detallada consultar en el texto.

tude of E1 and E2 lies between 6.3 and 6.8, according to empirical relationship for normal faulting and vertical throw of Wells and Coppersmith (1994). Lacustrine seismites consisting of fault-graded-beds coincide in age with the younger event (E2). A possible older earthquake dated 31,000 CALBP could be assigned in this trench, although with no hints for magnitude recognized.

Archaeoseismic evidence shows a horizon of destruction associated with the same dates obtained from the trench. However, other horizons are not related with tectonic activity of the Pozohondo Fault, suggesting a far field effect for the Islamic earthquake, as well as for the Lisbon earthquake of 1755.

The Pozohondo fault presents a characteristic earthquake of magnitude $6.3<\mathrm{M}<6.8$ during the Holocene, with a recurrence period of 6600-8600 yrs, approximately. The tectonic slip-rate estimated for the Holocene is 0.1 $\mathrm{mm} / \mathrm{yr}$, slightly higher than the slip-rate during the Late
Miocene $(0.05 \mathrm{~mm} / \mathrm{yr})$ and the Middle-Late Pleistocene (0.06-0.09 mm/yr).

Apparently, there is a slowly increasing tectonic activity in the Prebetic Zone, namely for the Pozohondo Fault, although the main coseismic activity shows a episodic dynamic.

\section{Acknowledgements}

We are grateful to Pr. José Pedro Calvo and Dr. Christoph Grützner for his helpful comments and fruitful discussion. This work was supported by the Spanish Project: ACTISIS (CGL2006-05001/BTE) of the ancient Ministry of Science and Innovation of Spain. Radiocarbon ages were obtained at the National Ocean Sciences Accelerator Mass Spectrometry Facility (NOSAMS) of Woods Hole Oceanographic Institution (USA). Also thanks are given to the "Consejería de Agricultura y Me- 
dio Ambiente" of Albacete for the drilling permission. Special mention to Emilio Usaola for his invaluable work during the trench fields and core sampling performed at the Alboraj Lake.

\section{References}

Angelier, J., Mechler, P. (1977): Sur une méthode graphice de recherche des contraintes principales également utilisable en tectonique et en séismologie: La méthode des dièdres droits. Bull. Soc. Geol. France 7, 1309-1318.

Calvo, J.P., Rodríguez-Pascua, M.A., Martín-Velázquez, S., Ximénez, S., and De Vicente, G. (1998): Microdeformation of lacustrine laminate sequences. An interpretation of loop-bedding. Sedimentology 45, 279-292. doi: 10.1046/j.1365-3091.1998.00145.x.

Fairbanks, R.G., Mortlock, R.A., Chiu, T.-Ch., Cao, L., Kaplan, A., Guilderson, T.P., Fairbanks, T.W., Bloom, A.L., Grootes, P.M., Nadeau M.J. (2005): Radiocarbon calibration curve spanning 0 to 50,000 years BP based on paired ${ }^{230} \mathrm{Th} /{ }^{234} \mathrm{U} /{ }^{238} \mathrm{U}$ and ${ }^{14} \mathrm{C}$ dates on pristine corals. Quaternary Science Reviews 24, 1781-1796. doi:10.1016/j.quascirev.2005.04.007.

García del Cura, M.A., Ordóñez, S., Calvo, J.P. (1979): Estudio sedimentológico de la cuenca cuaternaria de Cordovilla (Provincia de Albacete). En: CSIC (ed.), Actas de la III Reunión Nacional del Grupo Español de Trabajo del Cuaternario, 247-257. Zaragoza.

Jérez-Mir, L. (1973): Geología de la zona Prebética en la transversal de Elche de la Sierra y sectores adyacentes (provincias de Albacete y Murcia). Ph.D. dissertation, Universidad de Granada, 300 p.

Jerez-Mir, L. (1980): Mapa geológico de España E. 1:50.000. Hoja de Hellín, no: 843. IGME. Madrid.

McCalpin, J. (2009): Paleoseismology. $2^{\text {nd }}$ Edition. Elsevier. San Diego (USA). 613 p.

Pérez-López, R., Rodríguez-Pascua, M.A., Giner-Robles, J.L., Calvo, J.P., Garduño-Monroy, V.H., Israde-Alcantara, I., Bischoff, J. (2007): Calibration of the diffusion constant (K0) for dating coseismic fault scarps by using the diffusion equation: Application to the Alboraj earthquake, Albacete, SE Spain. In: Lario, J., and Silva, P.G. (eds.). Contribuciones al Estudio del Periodo Cuaternario: Avila, Spain, Asociación Española para el Estudio del Cuaternario, p. 161-162.

Rodríguez-Pascua, M. A., Calvo, J. P., De Vicente, G. Gómez-Gras, D. (2000a): Soft-sediment deformation structures interpreted as seismites in lacustrine sediments of the Prebetic Zone, SE Spain, and their potential use as indicators of earthquake magnitudes during the Late Miocene. Sedimentary Geology 135 (1-4), 117-135. doi:org/10.1016/S0037-0738(00)00067-1.
Rodríguez Pascua, M.A., De Vicente G. Calvo, J.P. (2000b): Subsidencia sísmica en las cuencas neógenas lacustres del Prebético de Albacete. Geotemas 1(4), 355-358. .

Rodríguez-Pascua, M.A. (2001): Paleosismicidad y sismotectónica de las cuencas lacustres neógenas del Prebético de Albacete. Instituto de Estudios Albacetenses, 123. Albacete. 285 p.

Rodríguez-Pascua, M.A., de Vicente, G. (2001): Estado de esfuerzos actual en la Cordillera Bética Oriental. Boletín Geológico y Minero de España 112(4), 79-95.

Rodríguez-Pascua, M.A., De Vicente, G., Calvo, J.P. Perez-Lopez, R. (2003): Similarities between recent seismic activity and paleoseismites during the late miocene in the external Betic Chain (Spain): relationship by the ' $b$ ' value and the fractal dimension. Journal of Structural Geology 25(5), 749-763. doi: 10.1016/S01918141(02)00078-0.

Rodríguez-Pascua, M.A., Pérez-López, R., Calvo, J.P. García del Cura, M.A. (2008): Recent seismogenic fault activity in a Late Quaternary closed-lake graben basin (Albacete, SE Spain). Geomorphology 102(1), 169-178. doi: 10.1016/j.geomorph.2007.06.023.

Rodríguez-Pascua, M.A., Bischoff, J., Garduno-Monroy, V. H., PérezLópez, R., Giner-Robles, J.L., Israde-Alcantara, I., Calvo, J.P., Williams, R. W. (2009): Estimation of the tectonic slip-rate from Quaternary lacustrine facies within the intraplate Albacete province (SE of Spain). Sedimentary Geology 222(1-2), 89-97. doi: 10.1016/j. sedgeo.2009.06.007.

Rodríguez-Pascua, M.A., Silva, P.G., Garduño-Monroy, V.H., PérezLópez, R., Israde-Alcántara, I., Giner-Robles, J.L., Bischoff, J.L., Calvo, J.P. (2010): Ancient earthquakes from archaeoseismic evidence during the Visigothic and Islamic periods in the archaeological site of "Tolmo de Minateda" (SE Spain). In: Sintubin, M., Stewart, I.S., Niemi, T.M., and Altunel, E. (eds.). Ancient Earthquakes: Geological Society of America Special Paper 471: 171-184. doi: 10.1130/2010.2471(15).

Seilacher, A. (1969): Fault graded beds interpreted as seismites. Sedimentology 13, 155-159.

Slemons, D.B. (1982): Determination of design earthquake magnitudes for microzonation. Proceedings of the $3^{\text {rd }}$ International Earthquake Microzonation Conference. Seattle, Washington, 119-130.

Urbina, F., Camacho, H. (1913): La zona megaseismica Acambay Tixmadeje, Estado de México, movida el 19 de noviembre de 1912. Boletín del Instituto Geológico de México, 32, 125 p.

Vegas, J., Rodríguez-Páscua, M.A., Perucha, M.A., Pérez-López, R., Israde Alcántara, I., Galán L., Mediato, J.F. (2012): Sismitas del siglo I al IV en la laguna de Alboraj (Holoceno superior, Albacete). Geotemas, in press.

Wells, D.L., Coppersmith, K.J. (1994): New empirical relationships among magnitude, rupture length, rupture width, rupture area, and surface displacement. Bulletin of the Seismological Society of America 84, 974-1002. 